\title{
Additional heat loss of jamb in enclosing structures
}

\author{
Maria Samsonova ${ }^{*}$ Elvira Semenova, Christina Kotova and Leonid Salogub \\ Voronezh State Technical University, 394006, 20 let Oktyabrya st., 84, Russian Federation
}

\begin{abstract}
One of the urgent problems today is to increase the energy efficiency of civil buildings. There is a need at the design stage to choose structures and design solutions that will compensate for the increasing consumption of energy resources in civil engineering. This article compares different building envelopes used in the construction of residential buildings: a volumetric block and a wall made of aerated concrete blocks. To determine the most energy efficient design solution construction is compared in different climatic regions. One of the most vulnerable places of a wall, from the point of view of energy efficiency, is a window jamb. In this article, an analysis is carried out to determine the construction with the lowest heat loss window jambs. Using the ELCUT software temperature fields and additional heat flux densities are calculated. According to the calculation, the proportion of heat loss due to window slope from heat loss according to the surface of the structure was determined. The heat flux density of the homogeneous section of the wall of the volume block is 1.28 times higher on average than in the aerated concrete wall. Regardless of the climatic conditions, the junction of the window jamb in buildings made of insulated panels of volumetric blocks is more energy efficient than the same junction in a building with aerated concrete walls.
\end{abstract}

\section{Introduction}

The rapid growth and development of modern cities leads to increased consumption of energy resources. This makes it necessary to compensate for the overall increase in resource consumption due to the introduction of modern energy-efficient and energy-saving technologies at the design stage $[1,2]$.

The object of the study is the window jambs of residential buildings made of volume unit and aerated concrete walls. According to $[3,4,5]$, the introduction of energy saving technologies at the design stage should be envisaged to improve the energy efficiency of civil buildings. Examples are given in $[6,7]$ to demonstrate that solutions will increase the level of comfort indoors and, in the course of operation, will lead to savings in energy resources and lower costs of their use.

\footnotetext{
* Corresponding author: samsonova.mary.11@gmail.com
} 
Heat loss of walls can reach $30 \%$, but this is mostly due to thermal conductive inclusions or cold joint. Their peculiarity is the appearance of additional heat flows, which reduce the overall heat transfer resistance of the enclosing structure and increase heat loss.

Since the share of heat loss from window slopes reaches $15 \%$ [1], identifying the least heat-intensive design solution is a solution to the pressing problem of building energyefficient buildings. Due to the use of modern quality thermal insulation materials (polystyrene foam) [8] and construction materials with lower heat transfer (aerated concrete, ceramic concrete blocks, porous ceramics) $[9,10]$ it is possible to achieve high performance of the energy efficiency class of the building.

The aim of the work is to compare the heat loss of window slopes of external walls made by an industrial method (volume blocks) [11], and constructions of the gas concrete walls erected directly on a building site are considered. Objective of the study is to compare the results of calculations of temperature fields, additional heat losses and their share of the main heat losses. For this purpose, we will define estimate indicator of constructions in countries with different climatic conditions, where industrial production of volumetric block buildings is carried out: Voronezh (Russia), Barcelona (Spain).

These indicators will make it possible to compare the energy efficiency of enclosing structures of volumetric-block buildings and buildings made of small-size elements in different climatic conditions.

\section{Methods}

To determine the additional capacity of thermal flows through the cold joint it is necessary to calculate the temperature fields. This calculation is performed for two variants of external enclosing structures of an apartment building (Fig.1). The first variant is wall panels of volumetric blocks, produced by Vybor OBD LLC (Russia, Voronezh) and CompactHabit (Spain, Barcelona). The second variant - enclosing structures made of aerated concrete blocks.

a)
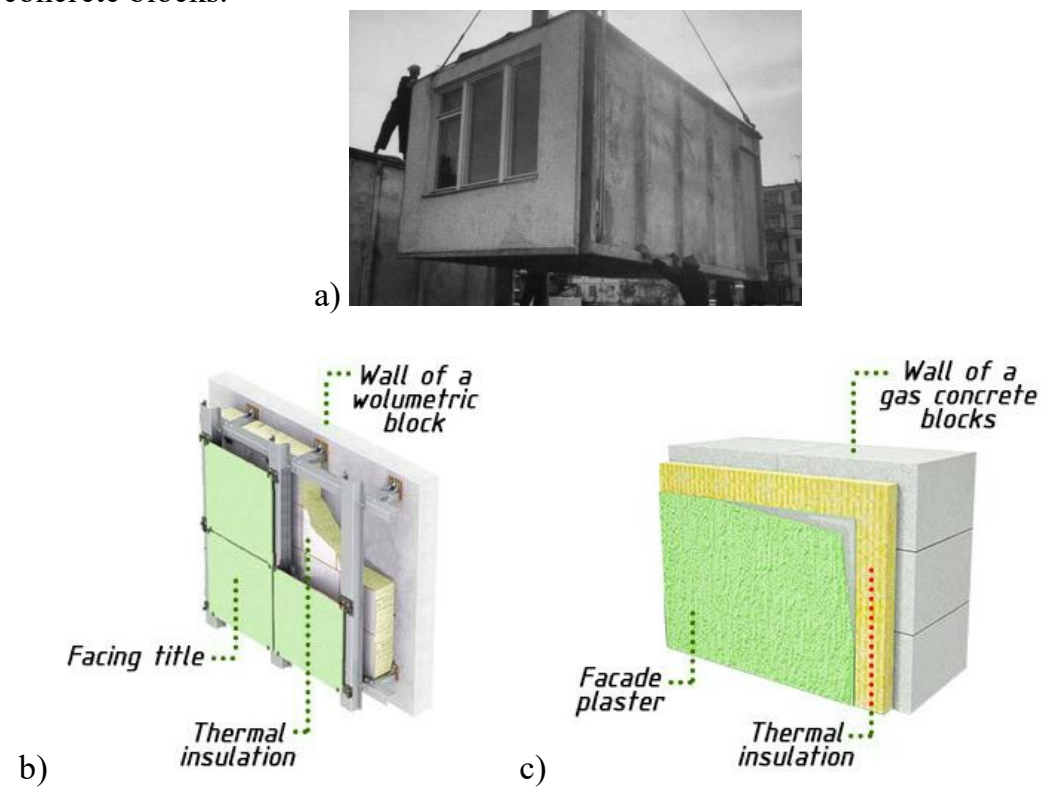

Fig. 1. General view of the investigated constructions: a - mounting of volumetric block; b construction of the external wall of the volumetric block; $\mathrm{c}$ - construction of the wall from gas concrete blocks 
Characteristics of climatic regions [12,13] are presented in table 1 , characteristics of compared materials of external enclosing structures $[14,15]$ are given in table 2 .

Table 1. Characteristics of climatic areas

\begin{tabular}{|c|c|c|c|c|}
\hline \multirow[t]{2}{*}{ Indicator name } & \multirow[t]{2}{*}{ Designation } & \multirow{2}{*}{$\begin{array}{c}\text { Units of } \\
\text { measurement }\end{array}$} & \multicolumn{2}{|c|}{$\begin{array}{c}\text { Indicators in climatic area } \\
\text { dependent }\end{array}$} \\
\hline & & & Barcelona & Voronezh \\
\hline $\begin{array}{l}\text { Temperature outside of the } \\
\text { coldest five days }\end{array}$ & $\mathrm{t}_{\mathrm{H}}$ & ${ }^{\circ} \mathrm{C}$ & 6.6 & -23 \\
\hline Duration heating season & $\mathrm{z}_{\text {оп }}$ & day/year & $\begin{array}{c}\text { Not } \\
\text { regulated }\end{array}$ & 190 \\
\hline Inside air temperature & $t_{B}$ & ${ }^{\circ} \mathrm{C}$ & 20 & 21 \\
\hline Inside air humidity & $\varphi$ & $\%$ & 50 & 55 \\
\hline $\begin{array}{l}\text { Heat-transfer coefficient of } \\
\text { internal wall surface }\end{array}$ & $\alpha_{\mathrm{B}}^{\mathrm{CT}}$ & \multirow{3}{*}{$\mathrm{W} /\left(\mathrm{m}^{2} \cdot{ }^{\circ} \mathrm{C}\right)$} & \multicolumn{2}{|c|}{8.7} \\
\hline $\begin{array}{l}\text { Heat-transfer coefficient of } \\
\text { internal window surface }\end{array}$ & $\alpha_{\mathrm{B}}^{\mathrm{oK}}$ & & \multicolumn{2}{|c|}{8.0} \\
\hline $\begin{array}{l}\text { Heat-transfer coefficient of } \\
\text { external wall surface }\end{array}$ & $\alpha_{\mathrm{H}}^{\mathrm{cT}}$ & & \multicolumn{2}{|c|}{23} \\
\hline
\end{tabular}

Table 2. Characteristics of comparable materials

\begin{tabular}{|c|c|c|}
\hline Indicator name & $\begin{array}{l}\text { Material density } \rho, \\
\mathrm{kg} / \mathrm{m}^{3}\end{array}$ & $\begin{array}{c}\text { Heat-transfer coefficient } \\
\lambda, \mathbf{W} /\left(\mathbf{m}^{2} \cdot{ }^{\circ} \mathbf{C}\right)\end{array}$ \\
\hline Reinforced concrete & 2500 & 1.7 \\
\hline Mineral wool board from stone fiber & 180 & 0.04 \\
\hline Gas-concrete block & 400 & 0.10 \\
\hline Facade plaster & 1800 & 0.93 \\
\hline PVC (polyvinylchloride) window profile & - & 0.08 \\
\hline Glass (5 mm thick) & 2500 & 0.76 \\
\hline Construction polyurethane foam & 80 & 0.05 \\
\hline
\end{tabular}

Fig. 2. shows the facade of the building under study. The facade area (including window apertures) is $472.01 \mathrm{~m}^{2}$. The size of window apertures: $1.84 \times 1.51 \mathrm{~m}$ (including balcony windows) - 30 pieces, $1.38 \times 1.51 \mathrm{~m}-10$ pieces. The area of the blind part of the facade is $F_{p}=367.82 \mathrm{~m}^{2}$. The total perimeter of all window slopes $(1, \mathrm{~m})$ is $258.8 \mathrm{~m}$. The assemblies of window slopes of the structures under study are shown in Fig. 3.

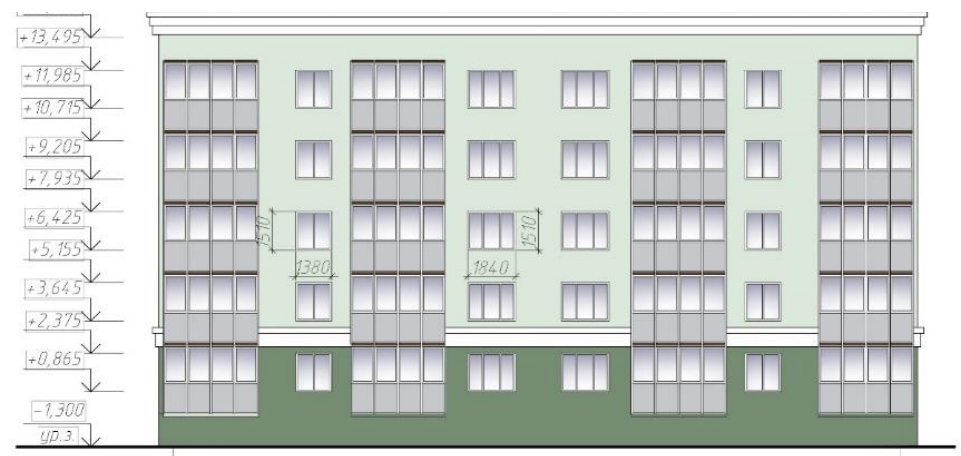

Fig. 2. Facade of the building under study 
a)
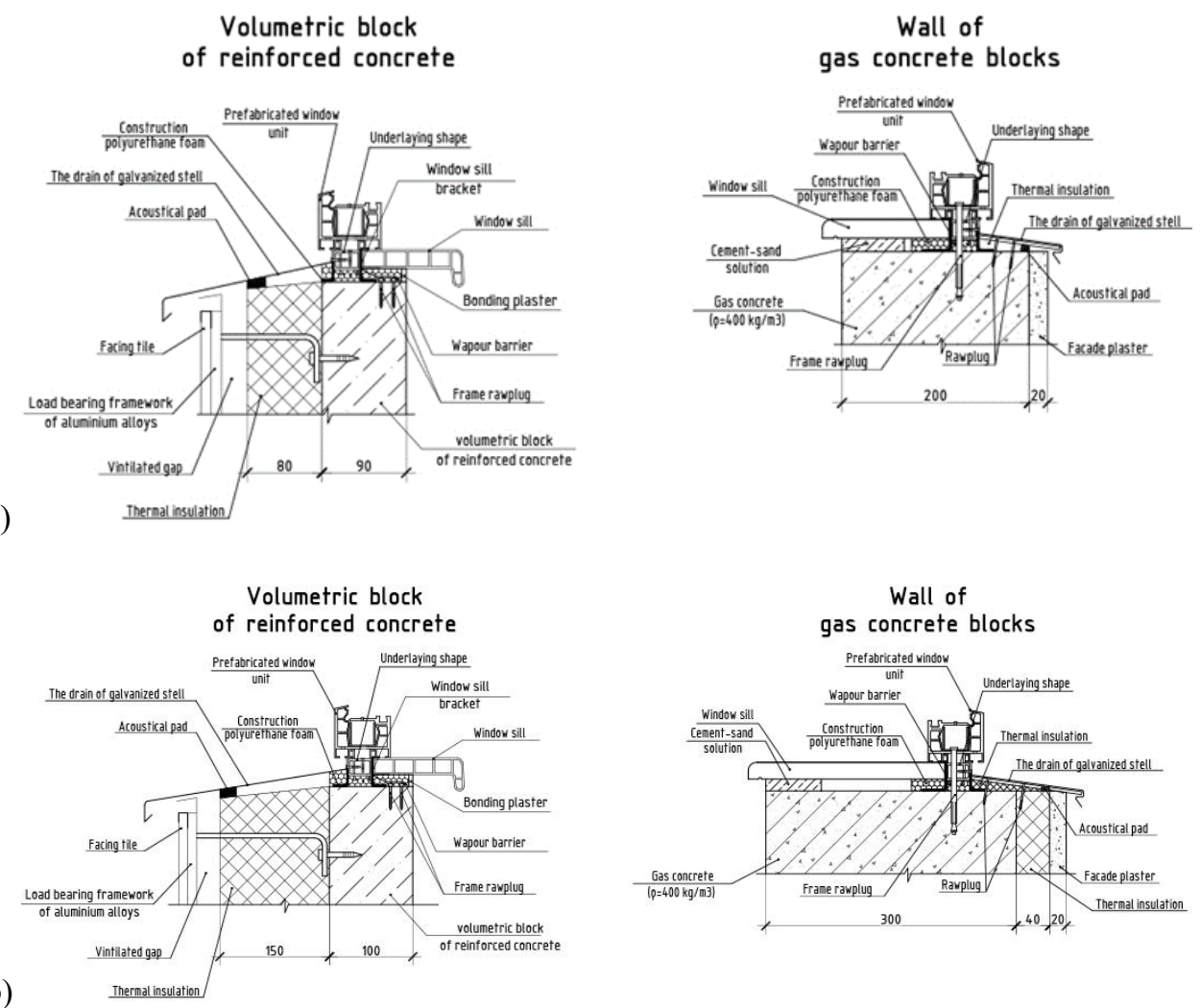

Fig. 3. Comparable variants of external enclosing structures: a - window jamb in comparable enclosing structures (Barcelona); b - window jamb in comparable enclosing structures (Voronezh);

To calculate the temperature fields, we will use the ELCUT software [16].

The obtained results of temperature field calculation should be processed and additional density of heat flow should be determined according to the method given in $[17,18]$. Table 3 shows the sequence of calculation of additional heat flux density.

Table 3. Calculation of additional heat flux density

\begin{tabular}{|c|c|c|}
\hline № & Indicator name & Formula and basic alphabetical symbols \\
\hline 1 & $\begin{array}{l}\text { Contingent resistance heat } \\
\text { interchange of outer wall }\end{array}$ & $\begin{array}{l}R_{0}^{\text {ycr }}=\left(\frac{1}{\alpha_{s}}+\sum_{i=1}^{n} \frac{\delta_{i}}{\lambda_{i}}+\frac{1}{\alpha_{u}}\right) r \\
\mathrm{r}-\text { heat transfer performance uniformity factor, } \\
\text { accepted for the construction of a ventilated facade } \\
0.75 \text {; for masonry of aerated concrete blocks } 0.85 \\
\text { according to p.4.4.2. [19] }\end{array}$ \\
\hline 2 & $\begin{array}{l}\text { Temperature at internal wall } \\
\text { surfaces }\end{array}$ & 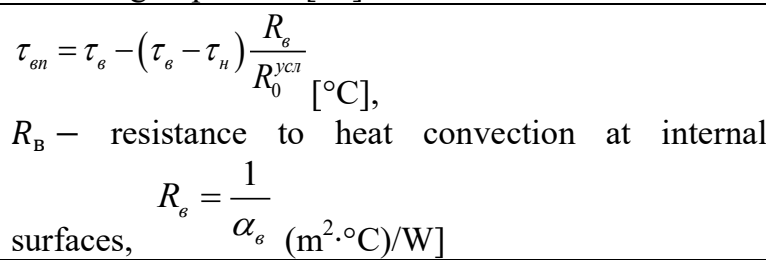 \\
\hline
\end{tabular}




\begin{tabular}{|c|c|c|}
\hline 3 & $\begin{array}{l}\text { Temperature at internal wall } \\
\text { surfaces in affected zone of } \\
\text { window jamb }\end{array}$ & $\begin{array}{l}\tau_{\mathrm{B} \Pi}^{\mathrm{T}}\left[{ }^{\circ} \mathrm{C}\right] \text { is determined by the results of temperature } \\
\text { field calculation. This is the area where there is a } \\
\text { change in temperature compared to the temperature } \\
\text { on the surface of the wall }[\mathrm{m}]\end{array}$ \\
\hline 4 & $\begin{array}{l}\text { Width of affected zone of } \\
\text { window jamb on the } \\
\text { temperature at internal wall } \\
\text { surfaces (section a) }\end{array}$ & $\begin{array}{l}\text { Determined by comparing the temperature on the } \\
\text { inner surface of the wall in the area of the window } \\
\text { jamb } \tau_{\mathrm{B \Pi}}^{\mathrm{T \Pi}} \text { with } \tau_{\mathrm{B \Pi}} \\
\mathrm{a}[\mathrm{m}]\end{array}$ \\
\hline 5 & $\begin{array}{l}\text { Heat flow capacity over a } \\
\text { section a for } 1 \mathrm{~m} \text { window } \\
\text { perimeter }\end{array}$ & $Q_{a}=\alpha_{\theta}\left(t_{s}-\tau_{s n}^{m n}\right)[\mathrm{W} / \mathrm{m}]$ \\
\hline 6 & $\begin{array}{l}\text { Heat flow capacity over a } \\
\text { wall surface of section a }\end{array}$ & $Q_{y c r}=\frac{\left(t_{\theta}-t_{H}\right)}{R_{0}^{y c l}} a[\mathrm{~W} / \mathrm{m}]$ \\
\hline 7 & $\begin{array}{l}\text { Variation of the capacity of } \\
\text { the heat flow through the } \\
\text { section a }\end{array}$ & $\Delta Q_{a}=Q_{a}-Q_{y c n}[\mathrm{~W} / \mathrm{m}]$ \\
\hline 8 & $\begin{array}{l}\text { Additional heat loss through } \\
\text { the inner window jamb } \\
\text { (section } b \text { ) }\end{array}$ & $\begin{array}{l}Q_{b}=\alpha_{b}\left(t_{b}-\tau_{b n}^{\text {omk }}\right) b[\mathrm{~W} / \mathrm{m}] \\
\tau_{\mathrm{B \Pi}}^{\text {oTK }}-\text { average temperature of the inner window jamb } \\
\text { surface }\left[{ }^{\circ} \mathrm{C}\right] \text { according to the calculation of } \\
\text { temperature fields; } \\
b \text { - width of the window jamb, } \mathrm{M}\end{array}$ \\
\hline 9 & $\begin{array}{l}\text { Additional heat flux density } \\
\text { through the window jamb at } \\
1 \mathrm{~m} \text { perimeter of the window } \\
\text { aperture }\end{array}$ & $Q_{\text {доп }}=\Delta Q_{a}+Q_{b}[\mathrm{~W} / \mathrm{m}]$ \\
\hline 10 & $\begin{array}{l}\text { Total number of running } \\
\text { meters of calculated sections } \\
\text { of window jambs }\end{array}$ & $\begin{array}{l}L=\frac{l}{F_{p}}\left[\mathrm{~m} / \mathrm{m}^{2}\right] \\
1-\text { total length of the calculated sections - the sum of } \\
\text { perimeters of all window jambs }[\mathrm{m}] ; \\
\mathrm{F}_{\mathrm{p}}-\text { calculated area - the area of the blind facade } \\
\text { (fig. } 2)\left[\mathrm{m}^{2}\right]\end{array}$ \\
\hline 11 & $\begin{array}{l}\text { Additional heat flux density, } \\
\text { caused by a window jamb }\end{array}$ & $q_{\text {до }}=Q_{\text {доn }} L\left[\mathrm{~W} / \mathrm{m}^{2}\right]$ \\
\hline 12 & $\begin{array}{l}\text { Heat flux density of a } \\
\text { homogeneous section of the } \\
\text { wall }\end{array}$ & $q=\frac{\left(t_{s}-t_{H}\right)}{R_{0}^{y c l}}\left[\mathrm{~W} / \mathrm{m}^{2}\right]$ \\
\hline 13 & $\begin{array}{l}\text { Percentage of heat loss due } \\
\text { to window jamb from heat } \\
\text { loss on the surface of the } \\
\text { wall }\end{array}$ & $\frac{q_{\partial o n}}{q} \cdot 100 \%$ \\
\hline
\end{tabular}

\section{Results and Discussion}

The results of calculation of temperature fields of window jamb for Voronezh and Barcelona are summarized in Table 4. Temperature fields of the window jambs and the temperature distribution are shown in the Fig. 4. The isotherms of the temperature fields are located in steps of $3{ }^{\circ} \mathrm{C}$. The method of calculation was performed according to [17]. The 
results of the calculations are compared with the results of studies conducted earlier in [7]. The distribution of heat flows in concrete materials is similar to those in the articles.

According to the data presented in the table, we will make a graph of dependence of additional heat losses on the outside air temperature and the design solution (Fig. 5).

Table 4. Results of calculation of additional heat flux density

\begin{tabular}{|c|c|c|c|c|c|}
\hline \multirow[b]{3}{*}{ № } & \multirow[b]{3}{*}{ Indicator name } & \multicolumn{4}{|c|}{ Indicator } \\
\hline & & \multicolumn{2}{|c|}{ Barcelona } & \multicolumn{2}{|c|}{ Voronezh } \\
\hline & & $\begin{array}{l}\text { volumetric } \\
\text { block }\end{array}$ & $\begin{array}{l}\text { the wall } \\
\text { from } \\
\text { aerated } \\
\text { concrete }\end{array}$ & $\begin{array}{l}\text { volumetric } \\
\text { block }\end{array}$ & $\begin{array}{l}\text { the wall } \\
\text { from } \\
\text { aerated } \\
\text { concrete }\end{array}$ \\
\hline 1 & $\begin{array}{l}\text { Contingent resistance heat } \\
\text { interchange of outer wall, } \\
R_{0}^{\mathrm{ycs}}\left[\left(\mathrm{m} 2 \cdot{ }^{\circ} \mathrm{C}\right) / \mathrm{W}\right]\end{array}$ & 1.659 & 2.975 & 2.975 & 3.553 \\
\hline 2 & $\begin{array}{l}\text { Temperature at internal wall } \\
\text { surfaces, } \tau_{\text {вп }}\left[{ }^{\circ} \mathrm{C}\right]\end{array}$ & 19.07 & 19.30 & 19.30 & 19.58 \\
\hline 3 & $\begin{array}{l}\text { Temperature at internal wall } \\
\text { surfaces in affected zone of } \\
\text { window jamb, } \tau_{\mathrm{B} \Pi}^{\mathrm{T \Pi}}\left[{ }^{\circ} \mathrm{C}\right]\end{array}$ & 20.00 & 20.73 & 20.73 & 19.03 \\
\hline 4 & $\begin{array}{l}\text { Width of affected zone of } \\
\text { window jamb on the } \\
\text { temperature at internal wall } \\
\text { surfaces (section a) }[\mathrm{m}]\end{array}$ & 0.120 & 0.014 & 0.014 & 0.140 \\
\hline 5 & $\begin{array}{l}\text { Heat flow capacity over a } \\
\text { section a for } 1 \mathrm{~m} \text { window } \\
\text { perimeter, } Q_{a}[\mathrm{~W} / \mathrm{m}]\end{array}$ & 0 & 0.033 & 0.033 & 2.399 \\
\hline 6 & $\begin{array}{l}\text { Heat flow capacity over a wall } \\
\text { surface of section a, } Q_{\text {усл, }} \\
{[\mathrm{W} / \mathrm{m}]}\end{array}$ & 0.969 & 0.212 & 0.212 & 1.773 \\
\hline 7 & $\begin{array}{l}\text { Variation of the capacity of } \\
\text { the heat flow through the } \\
\text { section a, } \Delta Q_{a}[\mathrm{~W} / \mathrm{m}]\end{array}$ & -0.969 & -0.179 & -0.179 & 0.626 \\
\hline 8 & $\begin{array}{l}\text { Additional heat loss through } \\
\text { the inner window jamb } \\
\text { (section } \mathrm{b}), Q_{b}[\mathrm{~W} / \mathrm{m}]\end{array}$ & 0 & 0.063 & 0.063 & 3.291 \\
\hline 9 & $\begin{array}{l}\text { Additional heat flux density } \\
\text { through the window jamb at } 1 \\
\mathrm{~m} \text { perimeter of the window } \\
\text { aperture, } Q_{\text {доп }}[\mathrm{W} / \mathrm{m}]\end{array}$ & -0.969 & -0.116 & -0.116 & 3.917 \\
\hline 10 & $\begin{array}{l}\text { Total number of running } \\
\text { meters of calculated sections } \\
\text { of window jambs, } L\left[\mathrm{~m} / \mathrm{m}^{2}\right]\end{array}$ & & & & \\
\hline 11 & $\begin{array}{l}\text { Additional heat flux density, } \\
\text { caused by a window jamb, } \\
q_{\text {доп }}\left[\mathrm{W} / \mathrm{m}^{2}\right]\end{array}$ & -0.682 & -0.082 & -0.082 & 2.758 \\
\hline 12 & $\begin{array}{l}\text { Heat flux density of a } \\
\text { homogeneous section of the } \\
\text { wall } q\left[\mathrm{~W} / \mathrm{m}^{2}\right]\end{array}$ & 8.08 & 14.79 & 14.79 & 12.38 \\
\hline 13 & $\begin{array}{l}\text { Percentage of heat loss due to } \\
\text { window jamb from heat loss } \\
\text { on the surface of the wall [\%] }\end{array}$ & 8.44 & 0.55 & 0.55 & 22.28 \\
\hline
\end{tabular}


a)

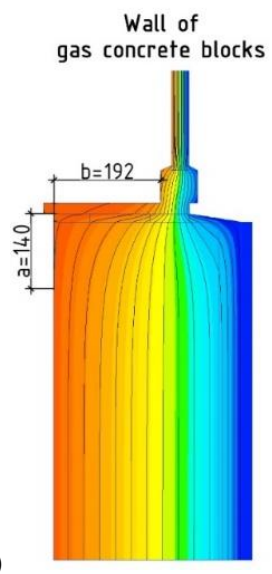

b)

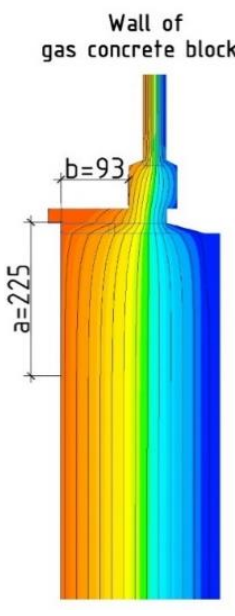

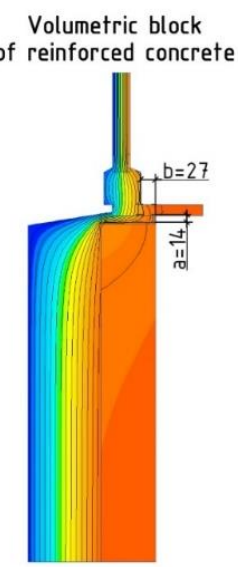

Volumetric block of reinforced concrete

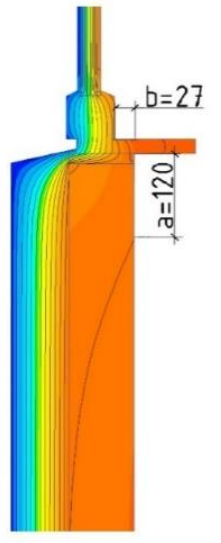

Temperature,

$\mathrm{T}\left({ }^{\circ} \mathrm{C}\right)$

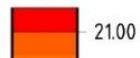

16.6

12.2

$-7.8$

$-3.4$

1.0

$-5.4$

$-9.0$

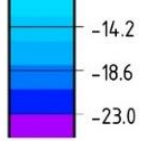

Temperature, $T\left({ }^{\circ} \mathrm{C}\right)$

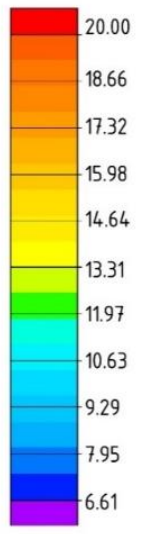

Fig. 4. Temperature fields of window jamb: $a$ - for Voronezh; $b$ - for Barcelona

The graph below (Fig. 5) shows the dependence of the share of heat loss of window jamb depending on the design solution and climatic conditions.

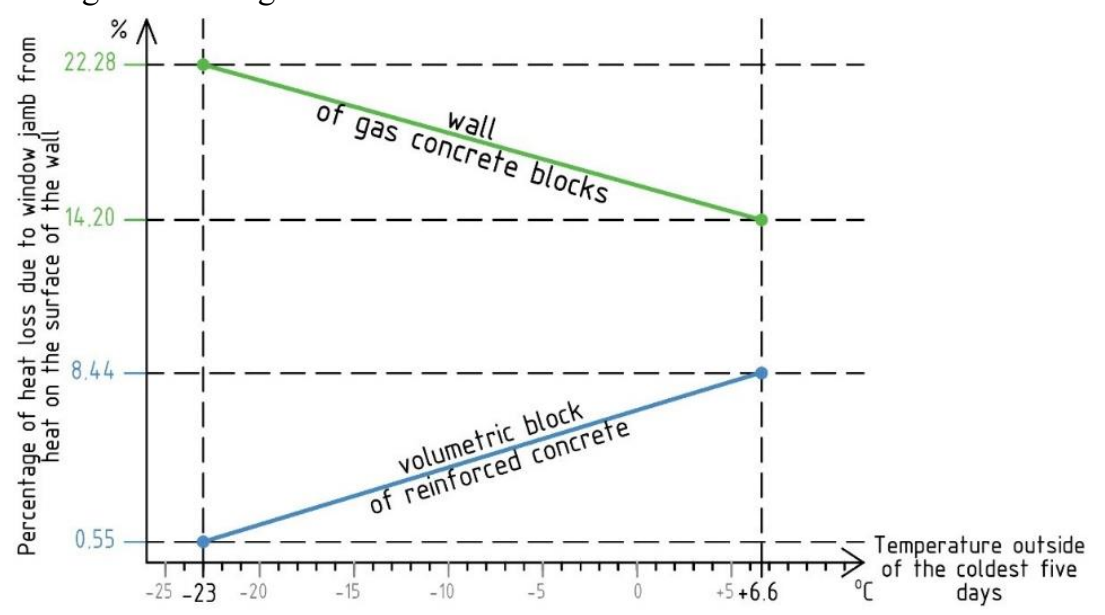

Fig. 5. Dependence of the share of heat loss on climatic conditions and structural design of the external enclosing structure 


\section{Conclusion}

1. Conducted research showed that the industrial construction method is the most energy efficient. The share of heat loss from the window jamb of volumetric block is $0.55 \%$ Voronezh, 8.44\% - Barcelona, which is 40.5 and 1.7 times less than the share of heat loss from the envelope made of the gas concrete block in these cities, respectively. The heat flux density of the homogeneous section of the wall of the volume block is 1.28 times higher on average than in the aerated concrete wall.

2. Having analysed the results, it can be concluded that regardless of the climatic conditions, the junction of the window jamb in buildings made of insulated panels of volumetric blocks is more energy efficient than the same junction in a building with aerated concrete walls.

3. The results presented in the article can be useful when submitting project documentation for examination.

\section{References}

1. D. Aydin, E. Mihlayanlar, A case study on the impact of building envelope on energy efficiency in high-rise residential buildings. ACEE. 13. Pp. 5-18 (2020)

2. Semenov V.N., Semenova E.E. Energy saving in building design as a key factor in the innovative development of the construction industry. Nedvizhimost': ekonomika, upravlenie. 3. Pp. 44-48 (2018)

3. S. Kim, J.D. Chang, J. Lim, Advanced Building Materials for Passive House and Energy Storage. Adv. Civ. Eng. (2017)

4. M. Ciampi , F. Fantozzi , F. Leccese \& G. Tuoni., On the optimization of building envelope thermal performance: Multi-layered wall design to minimize heating and cooling plant intervention in the case of time varying external temperature fields. Civ. Eng. Environ. Syst. 20. Pp. 231-254 (2003)

5. J. Parasonis, A. Keizikas, D. Kalibatiene, The relationship between the shape of a building and its energy performance. Arch. Eng. Des. Manag. 8. Pp. 246-256 (2012)

6. Semenova E.E., Gorbacheva O.N. Application of energy saving measures in construction. Tekhnicheskie nauki: tendencii, perspektivy i tekhnologii razvitiya / Sbornik nauchnyh trudov po itogam mezhdunarodnoj nauchnoprakticheskoj konferencii. 3. Pp. 97-100 (2016)

7. Duan Q., Wang J., Thermal Conditions Controlled by Thermostats: An Occupational Comfort and Well-being Perspective. Civ. Eng. Arch. 5. Pp. 173 - 179 (2017)

8. C. Monticelli, A. Zanelli, Material saving and building component efficiency as main eco-design principles for membrane architecture: case - studies of ETFE enclosures. Arch. Eng. Des. Manag. 16. Pp. 270-292 (2020)

9. Amin M. J., Morteza M., Naser P. S., Thermal and mechanical properties of PCMincorporated normal and lightweight concretes containing silica fume. Can. J. Civ. Eng. 46. Pp. 643-656 (2019)

10. Zaborova, D., Vieira, G., Musorina, T., Butyrin, A. Experimental Study of Thermal Stability of Building Materials. Adv. Intell. Syst. 692. Pp. $482-489$ (2018)

11. Semenova E.E., Gabitova S.O. Analysis of the implementation of energy-saving solutions in the design of civil buildings. Nauchnyj zhurnal. Inzhenernye sistemy $\mathrm{i}$ sooruzheniya. 28-29. Pp.41-45. (2017)

12. SP 131.13330.2012 Set of rules: Building climatology. 120 p. (2013) 
13. World climate guide. Climate - Barcelona. URL: https://www.climatestotravel.com/ climate/spain/barcelona (reference date: 10.04.2020)

14. Jiaqi C., HaoW., Pengyu X., Husam N., Analysis of thermal conductivity of porous concrete using laboratory measurements and microstructure models. Constr Build Mater. 218. Pp. 90-98 (2019)

15. ACI. P. 3: «Building Code Requirements for Reinforced Concrete». 524 p.

16. ELCUT. Simulation of two-dimensional fields by the finite element method (V. 5.10). Us. man. 339 p. (2009)

17. Tian L., Fangmei H., Jiang Z., Jinhui T., Jiaping L., Effect of foaming gas and cement type on the thermal conductivity of foamed concrete. Constr Build Mater. 231 (2020)

18. Lam T.V., Vu D., Zien V., Bulgakov B.I., Korol' E.A. Properties and thermal insulation efficiency of lightweight concrete. Mag. Civ. Eng. 84. Pp. 173-191 (2018)

19. SP 50.13330.2012 Set of rules: Thermal protection of buildings.100 p. (2012) 